\title{
THE PRICING OF SIZE, BOOK TO MARKET AND FINANCIAL LEVERAGE IN EURO STOCKS
}

Nawazish Mirza ${ }^{a}$, Mawal Sara Saeed ${ }^{b}$, Kumail Abbas Rizvi ${ }^{c}$

\footnotetext{
${ }^{a}$ Associate Professor (Finance), PhD, Center for Research in Economics and Business, Lahore School of Economics, Lahore, Pakistan.

${ }^{\mathrm{b}}$ Teaching Associate (Finance), MBA, Lahore School of Economics, Lahore, Pakistan.

'Assistant Professor (Finance), PhD, CFA, FRM, Lahore School of Economics, Lahore, Pakistan.
}

\section{ARTICLE INFO}

Article data:

- Received: 9 September 2011

- Accepted: 26 January 2012

JEL classification: G10, G12, G15

Keywords:

- Book to Market

- Size Premium

- Value Premium

- Financial Leverage

\section{ABSTRACT}

The relevance of financial leverage in a firm's capital structure holds great significance, however its role in asset pricing remains under investigated. In this paper we investigate if financial leverage is priced employing a sample of listed equities from nine European Union countries spanning over a period of twenty years (1989 - 2008). We form size, book to market, and leverage portfolios, to examine if leverage premium is systematic and whether augmenting the three factor model by including leverage variable would better explain the portfolio returns. Moreover, the paper investigates if size and value will capture financial distress in the presence of a superior measure based on net leverage. Our results suggest that the explanatory power of a four factor model is substantially superior to the "vanilla" version of a three factor model. Despite significant size and book to market coefficients, we could not find evidence that size and book to market factor capture financial distress in presence of a leverage mimicking factor.

Reference to this paper should be made as follows: Mirza, N. Saeed, M, S. Rizvi, K. 2013. The Pricing of Size, Book to Market and Financial Leverage in Euro Stocks, Ekonomska istraživanja - Economic Research 26(1): 1-16. 


\section{INTRODUCTION}

Financial leverage represents the capital mix that firms use to finance their asset base and it reflects the flexibility of a firm to raise incremental capital to sustain its business operations. Firms with higher debt ratios have an augmented cost of capital, which require higher coverages, and consequently, face difficulties in raising more capital. Firms with a weak equity base are sensitive to financial distress as a result of a consistently high leverage. Therefore, leverage is the primary source of financial risk that could lead to insolvency and bankruptcy of firms. Inspite of the critical role of leverage in a firm's funding and associated financial risk, capital mix as an essential factor has been largely ignored in asset pricing literature.

Modigliani and Miller (1958) proposed that expected return on equity should increase with an increase in financial leverage in the capital structure. This was substantiated by Hamada (1969), who combined the Modigliani - Miller proposition with capital asset pricing model (CAPM) of Sharpe (1964) and Lintner (1965), and suggested that an increase in financial leverage will result in an increase in the firm's beta. Therefore, if CAPM holds, financial risk from leverage will be captured by the beta coefficient, and hence does away with the need for a separate risk premium factor. However, the recent empirical evidence could not provide strong results in favor of CAPM, leading to the conclusion that a single factor beta could not solely explain the variation in stock returns.

The subsequent asset pricing propositions have extended the CAPM framework by including firm specific factor. Bhandari (1988) suggested that leverage is priced in stock returns and financial risk premium should be included as an independent risk factor. Fama and French (1992) criticized the inability of CAPM's beta to capture variation in stock returns and suggested a three factor model to include size $(\mathrm{SMB})$ and book to market $(\mathrm{HML})$ as additional explanatory variables. They argued that these factors explain the return premium that small firms receive over big firms and the premium higher book to market firms get over lower book to market firms.

The controversy around the three factor model relates to the type of risk, if any, captured by SMB (small minus big) and HML (high minus low) factor. Fama and French (1995) proposed that the three factor model has better explanatory power because size and value factor capture the financial risk emanating from an increase in financial leverage. They suggested that since financial distress is captured by book to market, leverage should not be priced as a separate factor. Vassalou and Xing (2004) examined the pricing of default risk for US equities in the context of three factor model. Their findings suggested that financial distress and default risk is systematic in nature and is priced in equity returns. They reported that SMB and HML contain some leverage related information, however that was not the only reason for these factor to be significant explanatory variables. As a result, they concluded that the three factor model augmented by a default factor that emanates from financial leverage is a better predictor of equity returns.

An increase in leverage conveys mixed signals to financial markets. On one side, this indicates possible investment opportunities for the firm which would be financed through debt acquisition, while on the other side, the incremental debt may exert pressure on the financial structure and increase financial risk. Despite the importance of financial leverage, there is scarce evidence in literature of the role of leverage vis-à-vis asset pricing. Moreover, such evidence is only for domestic markets and to the best of our knowledge, no study has attempted to examine the impact of leverage in cross country stock portfolios. The aim of this paper is two fold. We examine if leverage premium is systematic or not, and whether augmenting the three factor model through the leverage variable would better explain portfolio returns. Also, the paper investigates if $S M B$ and $H M L$ will capture financial distress in presence of leverage which is a primary indicator of financial panic. A sample of listed equities from nine European Union 
countries is used that spanned a period of twenty years (1989 - 2008) to examine if leverage is priced in global stock returns. To test for leverage premium, Fama and French size and book to market portfolios are extended to a three way sort by including a leverage mimicking portfolio to form a leverage factor $H L M L$ (high leverage minus low leverage). Our empirical results support the notion of leverage premium in international portfolios. The explanatory power of portfolio returns sorted for size, value, and leverage, substantially increased with the inclusion of the leverage factor, thereby validating the relevance of capital structure in pricing of financial assets. Moreover, inclusion of the leverage factor did not distort the explanatory power of SMB and $\mathrm{HML}$, indicating that Fama and French factor do not account for the financial distress from use of leverage - at least not in international portfolios.

This paper makes multiple contributions towards existing literature on asset pricing. Firstly, it introduces a net leverage based risk factor and mimicking leverage portfolios to explain the role of capital structure vis-à-vis risk premiums. Secondly, our sample constitutes of firms from various European countries and our evidence explains the risk return profile in international portfolios. Lastly, previous evidence demonstrates weak significance for size and value three factor model in international settings; however, we propose that Fama and French factor model augmented by a leverage premium factor better explains the variation in portfolio returns.

The rest of the paper is organized as follows. Section II will review some of the existing literature, Section III will discuss data and methodology, Section IV will comprise of empirical findings, and Section $V$ will conclude.

\section{LITERATURE REVIEW}

Most existing literature on financial leverage relates to the determinants of capital structure and the role of financial leverage as a risk factor in asset pricing has been largely ignored. There are however, evidences on the relationship between financial leverage and variation in stock returns. In this section, we present an overview of some existing literature on financial leverage and stock returns.

Bhandari (1988) investigated the role of financial leverage in explaining variation of US stock returns between 1948 and 1979. To analyze the impact of capital structure on stock returns, the estimates were controlled for beta and firm size along with January anomaly. The January anomaly refers to higher returns that cannot be explained with conventional asset pricing models. The results suggested a positive relationship between debt to equity ratio and stock returns, with higher stock returns for firms with high leverage compared to low leverage firms. They concluded that the risk which emerged from financial leverage is not covered by CAPM's beta and calls for a unique premium that is different from compensation of market risk.

Ferguson and Shockley (2003) reported the significance of firm's leverage and relative distress in asset pricing. They argue that empirical failure of CAPM is attributed to the widely used proxy of market returns from stock indices that only include equity investments, and neglect the debt claims. Their results suggest that the explanatory power of single factor models increase when they are augmented by leverage and distress. They concluded that in the presence of an all equity based market proxy, a leverage and distress augmented model outperformed the Fama and French three factor model in explaining cross sectional variation in returns.

Dhaliwal, Heitzman and Zhen (2006) examined the impact of financial leverage, corporate taxes, and personal taxes for investors, on the corporate cost of equity. The empirical findings demonstrate a positive relationship between leverage and cost of equity, which reflects an increasing risk premium for firms with high leverage. They also report a negative relationship between this equity premium and corporate tax rates. They concluded that an increase in a firm's leverage would increase the cost of equity; however, the tax benefits emanating from the presence of a tax shield would offset some of the leverage related equity premium. 
Penman, Richardson and Tuna (2007) decomposed the book to market ratio into two components: enterprise book to price, and leverage. The enterprise book to price was estimated as the ratio of book value to market value of operating assets. This ratio aims to capture the operating risk while the leverage component, measured as net debt to equity, was expected to reflect the financing risk. Their results suggest a positive relationship between operating risk and returns and a negative relationship of leverage with stock returns. They concluded that the negative relationship between leverage and returns was surprising, and attributed the possibility to be sample specific that warrants some more control variables.

Campbell, Hilscher and Szilagyi (2008) posed a serious challenge to the claims that size and value factor proxy financial distress premium. They noted that financially distressed stocks, despite having high volatilities, market beta and size and value loadings, were offering low returns. To account for the distress anomaly, they proposed a hazard model for default prediction comprising of firm specific variables, notably, leverage and cash holdings, and reported that firms with high leverage and low cash holdings are more likely to file for bankruptcy. They further demonstrated a strong negative correlation of abnormal returns with the bankruptcy risk as captured by their model. These findings remained robust even after conditioning on size and book and market. Campbell et al (2008) concluded that investors require risk premium for investing in financially challenged stocks and $\mathrm{SMB}$ and $\mathrm{HML}$ factor do not account for distress risk.

Wah, Strange and Piesse (2008) studied the impact of corporate financial leverage on asset pricing using stocks from the Hong Kong market between 1980 and 1998. Their results reported evidence for pricing of financial leverage in stock returns. These results remained robust in conditional estimations when data was segmented into bearish and bullish markets. They concluded that leverage is a relevant risk factor along with beta, size, and book to market, and is consequently priced in stock returns.

George and Hwang (2010) analyzed the relationship between stock returns, leverage and distress intensity, for a sample of firms from NYSE, Amex and Nasdaq between 1965 and 2003. They observed a negative relationship between stock returns and distress intensity and suggested that firms maintain capital structure based on distress costs. Firms with high costs are expected to maintain low leverage to avoid probability of financial distress. The higher equity participation exposes firms to more systematic risk as compared to firms with high leverage, and therefore calls for a higher market premium. Furthermore, they observe that inclusion of leverage or default probability does not erode the significance of book to market. They concluded that book to market ratio does not act as a proxy for financial distress or any other risk related to capital structure.

\section{DATA AND METHODOLOGY}

\section{A. Data and Sample}

The data for this study comprises of listed non financial stocks from nine European countries. These euro currency countries include Austria, Belgium, Finland, France, Germany, Ireland, Italy, Netherlands and Spain. Our sample period with monthly frequency spans over twenty years between 1989 and 2008. We do not include period after 2008 as it is marked with extreme financial turbulence where asset pricing dynamics are expected to depict extreme volatility. The initial sample constitutes all listed firm from these nine countries whose month end dividend adjusted prices are available on Thomson data stream. To be eligible for inclusion in sample in a particular year $t+1$, the selected stocks should have fundamental data available in year $t$. The fundamental data includes book value of equity, book value of long term debt, book 
value of assets, and number of shares outstanding. The firm size is calculated as market price time outstanding shares, book to market is represented as the ratio of book value of equity to market value of equity, while leverage is computed as book value of net long term debt to book value of total assets.

The asset pricing models in general and three factor model in particular have been subject to the criticism of survivorship bias. To account for this issue, we adapt Fama and French (1993) and consider only those stocks for our final sample that have been listed for at least two years. Similarly, all those firms which have been delisted or merged were not considered in the sample. Moreover, firms with negative book value of equity were also discarded. The empirical tests of asset pricing are likely to be impacted by the frequency of trading. If in a portfolio, one stock is less frequently traded than the other, this could exhibit some serial autocorrelation ${ }^{1}$. This spurious autocorrelation in closing prices could bias the empirical results and to account for this, stocks which have zero returns for more than $85 \%$ of the observations were excluded. Lastly, for meaningful international portfolios cross country outliers are accounted for. The combined countries data is ranked on basis of firm size, book to market and leverage individually and remove top and lower $5 \%$ stocks from each ranking. Based on this criterion, the numbers of selected stocks from each country are reported in Table 1.

TABLE 1 : YEAR WISE SAMPLE STOCKS

\begin{tabular}{lccccc}
\hline & $\mathbf{1 9 9 0}$ & $\mathbf{1 9 9 5}$ & $\mathbf{2 0 0 0}$ & $\mathbf{2 0 0 5}$ & $\mathbf{2 0 0 8}$ \\
\hline Austria & 50 & 100 & 210 & 250 & 270 \\
Belgium & 45 & 110 & 230 & 260 & 280 \\
Finland & 30 & 80 & 100 & 120 & 130 \\
France & 100 & 280 & 500 & 680 & 720 \\
Germany & 140 & 350 & 630 & 820 & 850 \\
Ireland & 30 & 50 & 80 & 120 & 140 \\
Italy & 55 & 120 & 220 & 280 & 290 \\
Netherlands & 45 & 80 & 150 & 180 & 220 \\
Spain & 55 & 100 & 230 & 290 & 300 \\
\hline Total & 550 & 1270 & 2350 & 3000 & 3200 \\
\hline Source: DataStream and Authors' Estimations & & &
\end{tabular}

The firm size statistics for our sample are reported in Table 2. The average firm size is increasing over the years owing to both an increased number of firms in sample and their transition to ecology of large size. The difference between sample median and average over the years is due to diversified presence of large and small size firms that is vital to observe the relevance of a significant size effect. The firms above median will be classified as large firms while those below would be small firms. The average book to market ratio was maximum in 2003, while it was lowest in 1998. The median did not show any significant change throughout the sample

\footnotetext{
${ }^{1}$ After accounting for our sample criterion, we report a kurtosis of 2.95 and skewness of 0.004 . Hence, we can safely assume our returns' distribution to be normal. Our regression results had a Durbin Watson statistics close to 2, so our findings are not subject to any violation of OLS. DW statistics are not reported for space constraints and are available on request.
} 
period representing a maintained book to market profile of sample firms. The statistics on book to market and leverage ratio are reported in table 3.

\begin{tabular}{lllllllllll}
\hline & 1989 & 1990 & 1991 & 1992 & 1993 & 1994 & 1995 & 1996 & 1997 & 1998 \\
\hline Median & 0.53 & 0.48 & 0.55 & 0.57 & 0.66 & 0.53 & 0.65 & 0.60 & 0.54 & 0.42 \\
Average & 0.70 & 0.60 & 0.70 & 0.72 & 0.79 & 0.60 & 0.75 & 0.72 & 0.68 & 0.54 \\
Std Dev & 1.28 & 0.78 & 0.58 & 0.50 & 0.53 & 0.35 & 0.52 & 0.66 & 0.57 & 0.57
\end{tabular}

Descriptive Statistics : Net Debt to Total Assets

\begin{tabular}{lcccccccccc}
\hline & 1989 & 1990 & 1991 & 1992 & 1993 & 1994 & 1995 & 1996 & 1997 & 1998 \\
\hline Median & 34.61 & 36.08 & 37.24 & 38.87 & 37.45 & 35.72 & 34.71 & 33.92 & 33.08 & 33.68 \\
Average & 35.70 & 37.01 & 38.06 & 39.30 & 38.77 & 37.27 & 36.62 & 37.22 & 36.87 & 36.11 \\
Std Dev & 20.77 & 20.27 & 20.82 & 21.66 & 22.36 & 21.73 & 21.12 & 22.38 & 26.29 & 25.73 \\
\hline
\end{tabular}

TABLE 2: DESCRIPTIVE STATISTICS FIRM SIZE

\begin{tabular}{|c|c|c|c|c|c|c|c|c|c|c|}
\hline & & 1990 & 1993 & 1994 & 1995 & 1996 & 1997 & 1998 & & \\
\hline & Median & 118.48 & 76.32 & 94.67 & 96.54 & 108.75 & 127.38 & 145.90 & & \\
\hline & Average & 764.29 & 759.90 & 868.13 & 859.08 & 1097.62 & 1564.52 & 1789.56 & & \\
\hline & Std Dev & 2372.14 & 2666.81 & 2841.82 & 2830.74 & 3836.00 & 6013.93 & 6816.03 & & \\
\hline & 1999 & 2000 & 2001 & 2002 & 2003 & 2004 & 2005 & 2006 & 2007 & 2008 \\
\hline Median & 118.54 & 138.07 & 86.04 & 56.54 & 53.59 & 67.86 & 91.05 & 106.86 & 122.87 & 85.37 \\
\hline Average & 1700.39 & 2119.06 & 1697.74 & 1371.21 & 1100.77 & 1363.86 & 1620.65 & 1804.84 & 2199.89 & 1695.41 \\
\hline Std Dev & 7516.09 & 10291.34 & 8198.59 & 6722.32 & 5270.10 & 6199.45 & 7541.51 & 7892.86 & 9502.64 & 7875.12 \\
\hline
\end{tabular}

Source: DataStream and Authors' Estimations

TABLE 3

\section{Descriptive Statistics: Book to Market}

Descriptive Statistics: Book to Market

\begin{tabular}{|c|c|c|c|c|c|c|c|c|c|c|c|}
\hline & 1989 & 1999 & 2000 & 2001 & 2002 & 2003 & 2004 & 2005 & 2006 & 2007 & 2008 \\
\hline Median & 0.53 & 0.50 & 0.43 & 0.53 & 0.62 & 0.83 & 0.60 & 0.58 & 0.47 & 0.43 & 0.56 \\
\hline Average & 0.70 & 0.64 & 0.58 & 0.67 & 1.06 & 1.29 & 1.12 & 1.14 & 0.91 & 0.86 & 1.04 \\
\hline Std Dev & 1.28 & 0.59 & 0.58 & 0.59 & 2.59 & 2.45 & 3.04 & 3.30 & 2.88 & 2.79 & 2.87 \\
\hline \multicolumn{12}{|c|}{ Descriptive Statistics : Net Debt to Total Assets } \\
\hline & 1989 & 1999 & 2000 & 2001 & 2002 & 2003 & 2004 & 2005 & 2006 & 2007 & 2008 \\
\hline Median & 34.61 & 32.83 & 31.21 & 33.50 & 34.35 & 34.09 & 33.20 & 30.78 & 30.44 & 30.91 & 36.52 \\
\hline Average & 35.70 & 35.63 & 33.70 & 35.44 & 37.09 & 37.05 & 36.33 & 35.12 & 34.01 & 33.87 & 37.06 \\
\hline Std Dev & 20.77 & 24.00 & 22.99 & 25.35 & 25.47 & 26.53 & 27.46 & 25.90 & 23.51 & 22.07 & 21.86 \\
\hline
\end{tabular}


The average leverage of sample firms has been range bound between $30 \%$ and $37 \%$ depicting no substantial overall variation in the capital mix of the selected firms. The choice of book value of leverage instead of market value is primarily for two main reasons. Firstly, market value is not observable for bank borrowings and privately placed funds, leaving book value of debt as general representation for financial leverage. Secondly, book leverage represents more closely the actual cash flow that is available to managers for capital budgeting purposes ${ }^{2}$. Therefore, the long term debt is adjusted for available cash and equivalents to get net long term debt. The net debt would account for the available cushion and represent a more accurate measure of financial risk emanating from capital structure. The median leverage ratio is then used to sort firms into a high leverage and a low leverage group.

The selected stocks will be combined to form international portfolios. One issue in cross country portfolios relates to the difference in currencies. However, our sample countries are all Euro denominated and even pre 2001 price data from Thomson Financial is available in Euros, hence the prices are already homogenized in a single currency. Based on month end prices, the logarithmic returns of the following form will be computed.

$R_{i(t)}=L N\left[\frac{P_{i(t)}}{P_{i(t-1)}}\right]$, where $R_{i(t)}$ represents return for stock $i$ in month $t$ while $P_{i(t)}$ and $P_{i(t-1)}$ represent price (in euro) for stock $i$ in month $t$ and $t-1$ respectively. These individual returns are then used to estimate value weighted portfolios that are constructed using the following procedure.

\section{B. Portfolio Construction}

The portfolios are constructed using a three way sort based on size, book to market, and leverage factor. The sample stocks from all countries are combined and ranked on the basis of size. The median for market value of equity in year $t$ is used as a cut off point for a firm to be classified as big (B) or small $(S)$ in year $t+1$. Once the two groups based on size are created, the firms in these groups are sorted into three book to market portfolios using book to market ratio with top 30\% as high $(\mathrm{H})$, middle $40 \%$ as $(\mathrm{M})$ and bottom $30 \%$ as low $(\mathrm{L})$. The result is six size and book to market portfolios with three book to market portfolios in each size group. The stocks from these six portfolios are then ranked on the basis of their leverage ratio. There are numerous financial ratios that are acceptable to depict the financial leverage of a firm. These include both long term and short term measures of leverage. The short term measures of leverage are relevant for the liquidity of a firm while the long term leverage ratios relate to the solvency and long term survival of a firm.

The main focus of this paper is on the pricing of risk premium that emanates from the use of leverage due to loss in financial flexibility and a potential increase in credit risk, therefore, net long term debt (long term debt less cash and cash equivalents) to total assets is taken as the relevant measure of leverage ${ }^{3}$. The stocks from the size and book to market portfolios are then

\footnotetext{
${ }^{2}$ We acknowledge that book value of debt adequately relates to available cash flows in the early years and with time the variance in book value of debt and cash flows will increase as accounting variables lose saliency while aging.

${ }^{3}$ We considered alternate definitions of leverage including total debt to total assets, long term debt (without adjusting for cash and equivalents) to total assets. The portfolios formed on these two leverage measures are not materially different from the one we are reporting in the paper and hence results remained robust. We are not reporting these for space constraints, however, they are available on request.
} 
ranked on the basis of leverage ratio and firms with debt ratio of more than the median are classified as high leverage $(H L)$, while those below median are recognised as low leverage stocks $(L L)$. This would result in a total of twelve value weighted portfolios at the intersection of size, book to market and leverage. These portfolios are rebalanced every year in June based on their respective market value of equity, book to market ratio, and financial leverage. Figure 1 illustrates the portfolio construction procedure.

Figure 1: Portfolio Construction Procedure

\begin{tabular}{|c|c|c|c|}
\hline Market Capitalization & Book to Market & Leverage & Portfolios \\
\hline \multirow{6}{*}{ Big MV } & \multirow{2}{*}{ High B/M } & Low Leverage & BHLL \\
\hline & & High Leverage & $\mathrm{BHHL}$ \\
\hline & \multirow{2}{*}{ Medium B/M } & Low Leverage & BMLL \\
\hline & & High Leverage & $\mathrm{BMHL}$ \\
\hline & \multirow{2}{*}{ Low B/M } & Low Leverage & BLLL \\
\hline & & High Leverage & BLHL \\
\hline \multirow{6}{*}{ Small MV } & \multirow{2}{*}{ High $B / M$} & Low Leverage & SHLL \\
\hline & & High Leverage & SHHL \\
\hline & \multirow{2}{*}{ Medium B/M } & Low Leverage & SMLL \\
\hline & & High Leverage & SMHL \\
\hline & \multirow{2}{*}{ Low B/M } & Low Leverage & SLLL \\
\hline & & High Leverage & SLHL \\
\hline
\end{tabular}

The names of these twelve portfolios represent their characteristics with respect to size, book to market and leverage. The portfolio BHHL includes stocks that are big in size with high book to market ratio and high financial leverage. Similarly, SLLL represents portfolio of stocks with small size, low book to market ratio and low financial leverage.

\section{Variables and Model Estimation}

The paper estimates a four factor asset pricing model that includes leverage as an explanatory variable for portfolio returns. The study also reports estimation of a single factor CAPM and Fama and French three factor model for twelve portfolios, and compares these results with a leverage augmented model. The regression equation (Ordinary Least Squares) that will be estimated for each of the twelve portfolios is represented as follows.

$$
R_{p(t)}-R_{f}=\alpha+\left(R_{m(t)}-R_{f}\right) \beta_{1 p}+\left(S M B_{t}\right) \beta_{2 p}+\left(H M L_{t}\right) \beta_{3 p}+(H L M L) \beta_{4 p}+\varepsilon_{t}
$$

Where $R_{p(t)}-R_{f}$ represents excess stock returns for each value weighted portfolio, $\left(R_{m(t)}-R_{f}\right)$ represents market risk premium, $S M B$ [small minus big] represents size premium, $H M L$ [high minus low] represents value premium, HLMLL [high leverage minus low leverage] is the proxy for 
leverage premium, while $\beta_{1 p}, \beta_{2 p}, \beta_{3 p}$ and $\beta_{4 p}$ are factor loadings for market, size, value and leverage premiums respectively.

The excess portfolio return is the difference between value weighted portfolio return and the risk free rate of yield on one month Treasury bill of France. The market risk premium is the difference between monthly return on S\&P Euro index and risk free rate. The size premium is the difference between arithmetic average return of six portfolios with small firms and that of large firms. Fama and French (1992) argue that small firms are more vulnerable to business volatility and therefore investors require a size premium while investing in these firms. The size premium will be calculated as follows.

$S M B=\frac{(S H H L+S H L L+S M H L+S M L L+S L H L+S L L L)}{6}-\frac{(B H H L+B H L L+B M H L+B M L L+B L H L+B L L L)}{6}$

The value premium accounts for the premium that investors demand for investing in value stocks over growth stocks. Value stocks are those that have high book to market ratio while stocks having low book to market stocks are categorised as growth stocks. Fama and French (1992) proposed value premium as compensation for investing in financially distressed firms that is reflected through a high book to market ratio. The value premium is the difference between the average returns on four value weighted portfolios with high book to market ratio and four portfolios with low book to market ratio. Mathematically it is,

$H M L=\frac{(B H H L+B H L L+S H H L+S H L L)}{4}-\frac{(B L H L+B L L L+S L H L+S L L L)}{4}$

We propose a leverage premium to account for the higher return on firms with a leveraged capital structure. This is in conjunction with Modigliani and Miller (1958) who proposed that the increase in leverage would result in an increase in required returns for equity and this increase in cost of equity would offset the benefits (mainly tax) derived from introducing leverage in capital structure. The leverage premium will be estimated as the difference between average returns of six high leverage portfolios and six low leverage portfolios.

Mathematically, $H L M L L$ is represented as

$H L M L L=\frac{(S H H L+B H H L+S M H L+B M H L+S L H L+B L H L)}{\text { The sorting process enfsures that each factor is }}-\frac{(S H L L+B H L L+S M L L+B M L L+S L L L+B L L L)}{\text { unique, so size will be free of value and }}$ leverage premium; similarly, value premium would be independent of size and leverage affects and same will be true for leverage premium. These factor will be used to estimate equations 1, 2 and 3. Fama and French (1992) contest that size and value factor are prices because investors require premium for firms that are financially distressed. Our leverage factor addresses the source of financial distress, i.e. the capital structure of a firm. If investors are sensitive towards financial leverage, significant coefficients for the leverage factor should be expected. Moreover, it should be noted that if $S M B$ and $H M L$ proxy some form of financial panic emanating from use of debt, then in presence of the leverage factor, the estimates of size and value premium in equation 3 should lose their significance in explaining portfolio returns. The dependent variables are excess returns on our 12 portfolios sorted for size, value and leverage factor. 


\section{EMPIRICAL RESULTS}

The regression estimates ${ }^{4}$ for CAPM, Fama and French three factor model and a leverage augmented four factor model are presented in Tables 4, 5 and 6, respectively. The regression coefficients for CAPM are discouraging for the time series model with insignificant risk premium and significant ${ }^{5}$ intercepts for all portfolios. This finding suggests that market risk premium is clearly not sufficient to explain the variation in portfolio returns. This evidence adds to the existing literature against CAPM, demonstrating poor performance of beta coefficient as the only systematic risk, especially when portfolios comprise of cross country stocks.

TABLE 4 : SINGLE FACTOR (CAPM) REGRESSION ON PORTFOLIOS SORTED FOR SIZE, BOOK TO MARKET AND LEVERAGE

\begin{tabular}{cllccc}
\hline & $\boldsymbol{\alpha}$ & $\boldsymbol{\beta}_{\mathbf{1}}$ & $\mathbf{t}(\boldsymbol{\alpha})$ & $\mathbf{t}\left(\boldsymbol{\beta}_{\mathbf{1}}\right)$ & $\mathbf{R}^{\mathbf{2}}$ \\
\hline BHLL & 0.00702 & -0.11113 & 2.95746 & -1.85402 & 0.01895 \\
BHHL & 0.00628 & -0.05817 & 2.18600 & -0.80152 & 0.00360 \\
BMLL & 0.00897 & -0.06927 & 3.69335 & -1.12956 & 0.00712 \\
BMHL & 0.00709 & -0.03792 & 2.74960 & -0.58214 & 0.00190 \\
BLLL & 0.01173 & -0.02381 & 4.53312 & -0.36433 & 0.00075 \\
BLHL & 0.00799 & -0.04065 & 2.95770 & -0.59596 & 0.00199 \\
SHLL & 0.00054 & -0.02198 & 0.21647 & -0.35035 & 0.00069 \\
SHHL & -0.00089 & -0.04524 & -0.35512 & -0.71705 & 0.00288 \\
SMLL & 0.00228 & -0.00014 & 0.95918 & -0.00236 & 0.00562 \\
SMHL & -0.00163 & -0.04504 & -0.74264 & -0.81333 & 0.00370 \\
SLLL & -0.00003 & -0.08277 & -0.01010 & -1.22674 & 0.00838 \\
SLHL & -0.00621 & -0.05425 & -2.44589 & -0.84669 & 0.00401 \\
\hline
\end{tabular}

Table 4 represents regression results for single factor CAPM with excess return as dependent while risk premium as independent variable. $\otimes$ represents the intercept for the model, while $\bigotimes_{1}$ is the loading on CAPM based risk premium with $t(\mathbb{\nabla})$ and $t\left(\mathbb{\bigotimes}_{1}\right)$ representing their respective statistical significance.

The results on Fama and French factor model provide evidence for size and value factor. It must be noted that beta coefficient in CAPM was the sole predictor of return while in multi factor models (Fama and French and the one augmented for leverage), the CAPM shares its prediction capacity with other risk premiums. The intercepts for all twelve portfolios are insignificant, which is an improvement as compared to CAPM results. The market risk premium is not significant at any instance, supporting our earlier finding that a CAPM based risk premium is not priced in international portfolios. The SMB factor loadings are significant and negative for big stocks (six portfolios) while they are insignificant for small firms. The negative sign of coefficients of big firms are in agreement with size proposition that suggests a negative relationship between $S M B$ factor and big stocks. The HML factor depicts a better explanatory power with significant coefficients for eight out of twelve portfolios. These eight portfolios include four high book to market and four low book to market portfolios. The coefficient signs are negative for low book to market firms while they are positive for high book to market firms. Given the significance of coefficients complemented by their signs, HML appears to be an explanatory factor for both high and low book to market stocks. Therefore, it can be concluded that both factors, particularly

\footnotetext{
${ }^{4}$ These time series regressions are estimated using EVIEWS.

${ }^{5}$ The significance level refers to $95 \%(t>1.96)$
} 
$H M L$, are predictors of international stock returns. For significant $S M B$ and $H M L$ regression estimates, we report a maximum adjusted $\mathrm{R}^{2}$ of $34.5 \%{ }^{6}$.

TABLE 5: THREE FACTOR REGRESSION ON PORTFOLIOS SORTED FOR SIZE, BOOK TO MARKET AND LEVERAGE

\begin{tabular}{cccccccccc}
\hline & $\boldsymbol{\alpha}$ & $\boldsymbol{\beta}_{1}$ & $\boldsymbol{\beta}_{2}$ & $\boldsymbol{\beta}_{3}$ & $\mathbf{t}(\boldsymbol{\alpha})$ & $\mathbf{t}\left(\boldsymbol{\beta}_{1}\right)$ & $\mathbf{t}\left(\boldsymbol{\beta}_{2}\right)$ & $\mathbf{t}\left(\boldsymbol{\beta}_{3}\right)$ & $\boldsymbol{R}^{2}$ \\
\hline BHLL & 0.000464 & -0.096902 & -0.720294 & 0.36955 & 0.19607 & -1.83377 & -5.955 & 4.108808 & 0.247089 \\
BHHL & -0.00352 & -0.037155 & -1.076908 & 0.523795 & -1.3282 & -0.62755 & -7.94646 & 5.197889 & 0.34523 \\
BMLL & 0.001604 & -0.057472 & -0.802488 & -0.05079 & 0.64219 & -1.03104 & -6.28955 & -0.53535 & 0.189963 \\
BMHL & -0.0017 & -0.023762 & -0.958147 & -0.052662 & -0.6613 & -0.41379 & -7.28926 & -0.53879 & 0.23387 \\
BLLL & 0.004716 & -0.01752 & -0.756301 & -0.599047 & 1.91363 & -0.31849 & -6.00631 & -6.39801 & 0.300785 \\
BLHL & -0.00166 & -0.027816 & -1.04722 & -0.358762 & -0.6468 & -0.48492 & -7.97583 & -3.67464 & 0.30295 \\
SHLL & 0.002888 & -0.021957 & 0.24994 & 0.437582 & 1.08218 & -0.36859 & 1.833012 & 4.315773 & 0.110295 \\
SHHL & -0.00019 & -0.041194 & 0.06766 & 0.579853 & -0.0729 & -0.70966 & 0.509235 & 5.869113 & 0.266048 \\
SMLL & 0.002646 & -0.001603 & 0.041717 & -0.094134 & 0.98219 & -0.02665 & 0.303131 & -0.91989 & 0.005366 \\
SMHL & -0.00203 & -0.044003 & -0.044596 & 0.040194 & -0.8147 & -0.79034 & -0.34994 & 0.424163 & 0.005445 \\
SLLL & 0.001459 & -0.090672 & 0.170836 & -0.605064 & 0.5246 & -1.4605 & 1.202186 & -5.72617 & 0.170981 \\
SLHL & -0.00487 & -0.0612 & 0.153084 & -0.526347 & -1.8168 & -1.02214 & 1.116986 & -5.1649 & 0.141399 \\
\hline
\end{tabular}

Table 5 represents regression results for Fama and Frecnch three factor model with excess return as dependent while risk premium, SMB (size) and HML (value) as independent variables. $\nabla$ represents the intercept for the model, while $\bigotimes_{1}, \bigotimes_{2}$ and $\bigotimes_{3}$ are loadings on CAPM based market risk premium, Size (SMB)

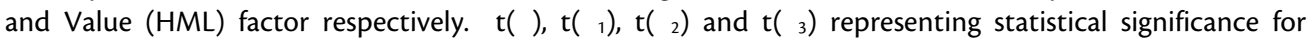
corresponding factor loadings.

The results for leverage augmented four factor model are encouraging. In 11 out of 12 portfolios significant slope coefficients for HLMLL are reported. The coefficient signs are negative for low leverage firms and positive for high leverage firms. This depicts a positive relationship between our leverage factor and firm leverage demonstrating pricing of leverage premium in portfolio returns. Since most of the portfolios of high and low leverage firms have significant betas for HLMLL, the capital structure is relevant in asset pricing for firms with leverage. The inclusion of leverage factor improved the significance of $\mathrm{SMB}$ and $\mathrm{HML}$ with non zero slopes on eight size portfolios and nine book to market portfolios. In the system regressions with leverage factor, SMB become marginally relevant for small firms with positive significant betas for two small portfolios. The average adjusted $\mathrm{R}^{2}$ for the three factor model regressions was $19.3 \%$ that increased to $31.9 \%$ with inclusion of leverage mimicking variable which indicates a significant improvement in variations explained by a four factor model.

\footnotetext{
${ }^{6} \mathrm{R}^{2}$ refers to coefficient of determination that present a meaningful measure of explanatory power of independent variables. A high coefficient will represent a higher tendency of explanatory variables to explain variations in dependent variable and vice versa.
} 
TABLE 6: FOUR FACTOR REGRESSIONS ON PORTFOLIOS SORTED FOR SIZE, BOOK TO MARKET AND LEVERAGE

\begin{tabular}{rrrrrr}
\hline & $\boldsymbol{\alpha}$ & $\boldsymbol{\beta}_{\mathbf{1}}$ & $\boldsymbol{\beta}_{2}$ & $\boldsymbol{\beta}_{3}$ & $\boldsymbol{\beta}_{4}$ \\
\hline BHLL & 0.001511 & -0.093274 & -0.797823 & 0.422775 & -0.426950 \\
& - & & & & \\
BHHL & 0.001434 & -0.040993 & -0.994904 & 0.467499 & 0.451591 \\
BMLL & 0.000958 & -0.056285 & -0.827846 & -0.033382 & -0.139644 \\
BMHL & 0.000092 & -0.026718 & -0.895000 & -0.096014 & 0.347750 \\
BLLL & 0.002692 & -0.013802 & -0.835742 & -0.544511 & -0.437474 \\
BLHL & 0.000324 & -0.030274 & -0.994710 & -0.394810 & 0.289171 \\
SHLL & 0.000364 & -0.015982 & 0.122279 & 0.525222 & -0.703018 \\
SHHL & 0.002900 & -0.046870 & 0.188929 & 0.496601 & 0.667818 \\
SMLL & 0.000559 & 0.002230 & -0.040168 & -0.037919 & -0.450931 \\
SMHL & 0.000030 & -0.047682 & 0.034002 & -0.013763 & 0.432832 \\
SLLL & 0.002046 & -0.084233 & 0.033275 & -0.510627 & -0.757539 \\
SLHL & 0.000731 & -0.068810 & 0.315658 & -0.637956 & 0.895283 \\
\hline
\end{tabular}

\begin{tabular}{llllll}
\hline $\mathbf{t}(\boldsymbol{\alpha})$ & $\mathbf{t}\left(\boldsymbol{\beta}_{1}\right)$ & $\mathbf{t}\left(\boldsymbol{\beta}_{2}\right)$ & $\mathbf{t}\left(\boldsymbol{\beta}_{3}\right)$ & $\mathbf{t}\left(\boldsymbol{\beta}_{4}\right)$ & $\mathbf{R}^{2}$ \\
\hline-0.599282 & -1.781718 & -6.372781 & 4.570234 & -2.126172 & 0.326048 \\
-0.506778 & -0.697918 & -7.082991 & 4.504260 & 2.004379 & 0.459924 \\
0.355929 & -1.007556 & -6.196816 & -0.338174 & -0.651688 & 0.231924 \\
-0.033529 & -0.467003 & -6.541535 & -2.949724 & 1.984615 & 0.294707 \\
1.025245 & -0.253157 & -6.410036 & -5.652000 & -2.091897 & 0.367843 \\
-0.117609 & -0.528583 & -7.262488 & -3.901080 & 2.316264 & 0.397830 \\
-0.130090 & -0.274866 & 0.879399 & 5.111898 & -3.152086 & 0.458094 \\
1.061180 & -0.826087 & 1.984370 & 4.953261 & 3.068554 & 0.309252 \\
0.194643 & 0.037374 & -0.281496 & -0.359637 & -1.970174 & 0.269480 \\
-0.011170 & -0.863651 & 0.257534 & -0.141080 & 2.043850 & 0.286320 \\
-0.702252 & -1.392799 & 0.230072 & -4.778151 & -3.265522 & 0.218596 \\
-0.264412 & -1.198182 & 2.298438 & -6.286572 & 4.064206 & 0.215451 \\
\hline
\end{tabular}

Table 6 represents regression results for four factor model (Fama and French augmented for leverage premium) with excess returns as dependent while risk premium, SMB (size), HML (value) and Leverage premium (HLMLL) as independent variables. $\nabla$ represents the intercept for the model, while $\nabla_{1}, \bigotimes_{2}, \bigotimes_{3}$ and $\nabla_{4}$ are loadings on CAPM based market risk premium, Size (SMB), Value (HML) and Leverage (HLMLL) factor respectively. $t\left(\mathbb{\Xi}_{)}\right), t\left(\mathbb{\bigotimes}_{1}\right), t\left(\mathbb{\bigotimes}_{2}\right), t\left(\mathbb{\Xi}_{3}\right)$ and $t\left(\mathbb{\bigotimes}_{4}\right)$ representing statistical significance for corresponding factor loadings.

These results have surprising implications for theoretical foundations of Fama and French factor that suggests the pricing of $\mathrm{SMB}$ and $\mathrm{HML}$ is to capture the premium for financially distressed firms. A firm would be in financial distress when it finds difficulty in honouring its creditors' obligations through free cash flows or by raising external capital. Therefore, firms with 
increased business risk and less financial flexibility could face such a condition. The primary indicator of financial distress is an increase in financial debt. An increasing net debt would put constraints on raising incremental capital and firms with high leverage would find it difficult and costly to access funds as compared to firms with less leverage. If $S M B$ and $H M L$ are reflecting financial panic of a firm then inclusion of HLMLL will be explaining a similar risk premium. Hence, a four factor model including SMB, HML and HLMLL will be insignificant or at least SMB and HML would lose their significance in presence of a superior proxy of distress. Clearly, this is not the case and results demonstrated that in four factor regressions, the overall explanatory power of the model improved substantially while the significance of coefficients on size and value premium remained intact.

These findings from regression estimates indicate that $S M B$ and $H M L$ are not a proxy for financial distress emanating from financial leverage, at least not for the international portfolios, and the leverage premium is systematic which should be priced separately. Our findings about size and value factor are similar to those of Vassalou and Xing (2004) who assessed the pricing of default risk in equity returns and concluded that significance of $S M B$ and $H M L$ is not related to default related information. However, it is important to note that the significance of SMB and $\mathrm{HML}$ factor clearly reflects that they are priced but, given our results, the nature of risk they specify remain a puzzle. Vassalou (2003) attributed the relevance of size and book to market factor to macroeconomic factors like news related to future GDP growth.

\section{CONCLUSION}

Earlier proposition of Modigliani and Miller (1958) who suggested that cost of equity will increase due to increase in debt was a part of limited literature on impact of leverage on stock returns. This paper notably extends the literature on asset pricing in an international context by investigating the impact of leverage mimicking factor portfolios on variations in stock returns. The main aim of the paper was to examine if a multi factor model including a leverage premium would better explain equity returns compared to a single factor CAPM and a size and book to market three factor model. Our findings suggest that CAPM based market risk is unable to explain any variation in returns with significant intercepts and insignificant betas for all regressions. The traditional three factor model provided a better estimate by capturing some of the variations. However, the four factor model that is augmented by leverage mimicking factor has superior explanatory power of explaining time series variations of stock returns and consequently leverage premium is a systematic risk that is priced in corresponding returns. We also observe that when leverage is regressed with size and book to market factor, the latter variables did not lose any significance, indicating that the three variables are priced for independent risks. Since the level of financial leverage is the primary reflection of financial distress of any firm, it can be concluded that although SMB and HML are significant, they do not account for financial distress as proposed by Fama and French (1995). The alternate explanations for existence of size and book to market effects in a domestic context find its origin in macroeconomic variables such as future GDP growth. The source of significance of SMB and HML in international portfolios is beyond the scope of this paper and we leave that to further research. 


\section{REFERENCES}

Bhandari, L., "Debt Equity Ratio and Expected Common Stock Returns: Empirical Evidence", Journal of Finance, 43 no 2 (1988): 507 - 528.

Campbell, Y., Hilscher, J. and Szilagyi, J., "In Search of Distress Risk", Journal of Finance, 63 no 6, (2008): $2899-2939$.

Dhaliwal, D., Heitzman, S. and Zhen Li, O., "Taxes, Leverage, and the Cost of Equity Capital", Journal of Accounting Research, 44 no 4 (2006): 691 - 723.

Fama, E. and French, K., "The Cross-Section of Expected Stock Returns", Journal of Finance, 47 no 2 (1992): 427-465.

Fama, E. and French, K., "Common Risk Factor in the Returns on Stocks and Bonds", Journal of Financial Economics, 33 no 1 (1993): 3-56.

Fama, E. and French, K., "Size and Book-to-Market Factor in Earnings and Returns", Journal of Finance, 50(1), pp. 131-155. (1995)

Ferguson, M. and Shockley, R., "Equilibrium Anomalies", Journal of Finance, 58 no 6 (2003): 2549 -2580 .

George, T. and Hwang, C., "A Resolution of the Distress Risk and Leverage Puzzles in the Cross Section of Stock Returns", Journal of Financial Economics, 96 (2010): 56 - 79.

Lintner, J., "The Valuation of Risk Assets and the Selection of Risky Investments in Stock Portfolios and Capital Budgets", Review of Economics and Statistics, 47 (1965): 13 - 37.

Modigliani, F. and Miller, M. "The Cost of Capital, Corporation Finance and the Theory of Investment", American Economic Review 48 no 3 (1958): 261-297.

Penman, S., Richardson, S. and Tuna, I., "The Book to Price Effect in Stock Returns: Accounting for Leverage", Journal of Accounting Research, 45 no 2 (2007): 427 - 467.

Sharpe, W. "Capital Asset Prices: A Theory of Market Equilibrium under Conditions of Risk", Journal of Finance, 19 no 3 (1964): 425-442.

Vassalou, M., "News related to Future GDP Growth as a Risk Factor in Equity Returns", Journal of Financial Economics, 68 (2003): 47-73.

Vassalou, M. and Xing, Y., "Default Risk in Equity Returns", Journal of Finance, 59 no 2 (2004): $831-868$.

Wah Ho, R., Strange, R. and Piesse, J., "Corporate Financial Leverage and Asset Pricing in the Hong Kong market", International Business Review, 17 (2008): 1 - 7. 